\title{
Monika Szustkowska
}

ORCID: 0000-0002-4928-6834

Samorządowe Centrum

Doradztwa i Doskonalenia Nauczycieli w Siedlcach

\section{Zdalne nauczanie uczniów z niepełnosprawnością}

\author{
Distance teaching of pupils with disabilities
}

https://doi.org/10.34739/sn.2020.20.09

Streszczenie: Artykuł dotyczy problematyki nauczania na odległość uczniów ze specjalnymi potrzebami edukacyjnymi oraz uczniów posiadających orzeczenie o potrzebie kształcenia specjalnego, a w szczególności problemów związanych z jego realizowaniem.

Słowa kluczowe: pandemia, nauczanie, edukacja, niepełnosprawność

Abstract: The article deals with the topic of students with special educational needs and students with a certificate of the need for special education in the course of distance learning

Keywords: pandemic, teaching, education, disability

Nauczanie zdalne dzieci niepełnosprawnych to spore wyzwanie zarówno dla nauczycieli i rodziców, jak i samych uczniów. Obserwujemy dyskusje o wykorzystaniu różnych form kształcenia na odległość do aktywizacji edukacyjnej osób z niepełnosprawnością. Zdalne kształcenie, pozwalające uczestniczyć osobom z ograniczoną sprawnością fizyczną czy intelektualną w środowisku edukacyjnym, jest w gruncie rzeczy atrakcyjne i wspomaga rozwój społeczny osób niepełnosprawnych. W czasie ograniczenia funkcjonowania szkół i placówek oświatowych zajęcia adresowane do uczniów ze specjalnymi potrzebami edukacyjnymi, w tym do tych objętych kształceniem specjalnym i pomocą psychologiczno-pedagogiczną, organizuje się uwzględniając metody i techniki kształcenia na odległość. Podsta- 
wowe założenie e-learningu to dostosowanie zasad współpracy do możliwości psychofizycznych uczniów.

Uczniowie ze specjalnymi potrzebami edukacyjnymi oraz uczniowie posiadający orzeczenie o potrzebie kształcenia specjalnego powinni zostać objęci szczególną opieką w trakcie realizacji nauczania na odległość. Należy pamiętać, że dla tych uczniów oraz dla uczniów z orzeczeniami niezmiernie ważne kwestie to m.in.: oswojenie się z nową rzeczywistością, z nieznanymi dotąd formami pracy i nieznanymi narzędziami informatycznymi, poradzenie sobie z izolacją od grupy rówieśniczej i z brakiem możliwości odczytywania uczuć innych ludzi podczas zdalnego nauczania, a w przypadku uczniów z autyzmem i Aspergerem - konieczność ograniczenia czasu spędzanego przed ekranem komputera, gdyż częste korzystanie z komputerów może powodować np. częstsze napady padaczkowe. Ważny jest także dobór narzędzi informatycznych odpowiednich do możliwości psychofizycznych uczniów [Kozimior-Cyganik, 2020]. Jednocześnie nowoczesne technologie umożliwiają dzieciom i młodzieży niepełnosprawnej dostęp do edukacji. E-nauka osób z niepełnosprawnością wymaga jednak stworzenia zarówno odpowiednich warunków organizacyjnych, jak i wprowadzenia rozwiązań systemowych dotyczących m.in.: kształcenia i doskonalenia nauczycieli w zakresie specjalnych potrzeb edukacyjnych, włączania form e-edukacji w powszechny system edukacji czy zapewnienia wsparcia technicznego dla kształcenia zdalnego osób niepełnosprawnych. [Wapiennik, 2005]. Tymczasem e-learning jako oferta skierowana do osób niepełnosprawnych w Polsce to oderwany od rzeczywistości projekt, a nie działania systemowe. Projekt ten skupia się na doskonaleniu osób dorosłych, poszukujących różnych form samokształcenia lub doskonalenia, które pozwoliłyby im odnaleźć swoje miejsce na rynku pracy, wciąż jednak brak spójnego systemu kształcenia, który uwzględniłby potrzeby osób niepełnosprawnych w różnym wieku.

Aby e-edukacja uczniów z niepełnosprawnością powiodła się, edukację zdalną należy zacząć od podstawowego poziomu trudności, czyli od prostych i łatwych zadań, z wykorzystaniem nieskomplikowanej grafiki. Istotnym elementem takich działań jest dostarczanie i otrzymywanie informacji zwrotnej na temat satysfakcji ze współpracy na linii 
szkoła-dom i dom-szkoła zarówno przez ucznia i jego rodziców, jak i nauczycieli. Niestety Rozporządzenie Ministra Edukacji Narodowej z dnia 20 marca 2020 r. w sprawie szczególnych rozwiązań w okresie czasowego ograniczenia funkcjonowania jednostek systemu oświaty w związku z zapobieganiem, przeciwdziałaniem i zwalczaniem COVID-19, nie zawiera gotowych rozwiązań, dotyczących realizacji podstawy programowej w przypadku uczniów posiadających orzeczenie o potrzebie kształcenia specjalnego ze względu na niepełnosprawność intelektualną. W przypadku dzieci objętych wychowaniem przedszkolnym, edukacją wczesnoszkolną, wczesnym wspomaganiem rozwoju, zajęciami rewalidacyjno-wychowawczymi czy uczniów niepełnosprawnych intelektualnie w stopniu umiarkowanym, znacznym lub z niepełnosprawnościami sprzężonymi, zajęcia w ramach kształcenia na odległość mogą być realizowane na zasadzie informowania rodziców o dostępnych materiałach i możliwych formach ich opracowania przez ucznia w domu [Kowalski, 2020]. Samo informowanie nie wystarczy. Oprócz informowania rodziców można również wdrażać inne formy kształcenia na odległość, jednak należy pamiętać, że nie ma złotego środka i jednego cudownego rozwiązania. Specyfika pracy pedagogów specjalnych i specyfika funkcjonowania szkół specjalnych jest bardzo różna. Aby właściwie i efektywnie zorganizować proces zdalnego nauczania dzieci z niepełnosprawnościami niezbędna jest współpraca ich nauczycieli i rodziców. Niestety nie można przejść przez to samodzielnie, bo prędzej czy później napotkamy na przeszkodę. Jeśli uczeń ze specjalnymi potrzebami edukacyjnymi lub uczeń posiadający orzeczenie o potrzebie kształcenia specjalnego nie jest w stanie zrealizować programu w sposób zdalny, należy wskazać mu alternatywną formę realizacji programu. Głównym zadaniem nauczycieli jest informowanie i podpowiadanie rodzicom, gdzie dostępne są informacje i materiały, które mogą oni wykorzystać z uczniami. Najprostszym rozwiązaniem jest skupienie się na przekazie tygodniowym, ustalenie współpracy na tydzień, a nie na każdy dzień tygodnia z osobna. Należy dostosować ilość treści i zadania do konkretnego ucznia. Kontakt z rodzicami ucznia to istotny element współpracy i gwarancja efektywności podjętych przez nauczyciela działań. Bez udziału rodziców niczego nie da się zorganizować ani wdrożyć, ponieważ to oni są sprzymierzeńcami na- 
uczyciela w relacjach i kontaktach z uczniami. Należy dobrze przemyśleć jaka forma kontaktu będzie najlepsza, jakim sprzętem dysponują uczniowie i czy możliwa jest bezpośrednia komunikacja.

Dla każdego dziecka, szczególnie w młodszym wieku szkolnym, nowa i nieznana sytuacja, której skutkami może być zagrożenie życia i zdrowia, może sprawić, że towarzyszyć jej będzie lęk i poczucie zagrożenia. Nie można lekceważyć takich emocji. To, co nam wydaje się mało istotne, u dzieci może powodować lęk, histerię, symulowanie choroby, wzrost temperatury ciała, a nawet zachowania niepożądane. Wbrew pozorom uczenie się nie jest najważniejsze w sytuacji kryzysowej, ale z pewnością jest znaczącym elementem wsparcia dzieci i stworzenia im chociaż namiastki normalności. W tym trudnym czasie należy skupić się na dozowaniu zadań i na ich kreatywnej formie. Tworząc warsztat pracy zdalnej, trzeba zastanowić się, czy wybrane metody i narzędzia są dostosowane do celów, jakie mają zostać osiągnięte, oraz w jaki sposób wybrane narzędzia oddziałują na uczniów. Zadania muszą uwzględniać zarówno pracę $w$ trybie synchronicznym, jak również asynchronicznym, zaś komunikacja z uczniami musi być możliwa za pośrednictwem różnych środków komunikacji.

W pracy z uczniami ze specjalnymi potrzebami edukacyjnymi, w szczególności z dziećmi z niepełnosprawnością intelektualną, należy skupić się na ich mocnych stronach, poprzez praktyczne i aktywne działanie. W wielu przypadkach istotny jest alternatywny sposób komunikacji oparty na piktogramach. Przekaz słowny nie przyniesie w tym przypadku żadnego skutku, a to sprawia, że pedagodzy specjalni są pełni obaw o to, jak zorganizować zdalne nauczanie, biorąc pod uwagę te wszystkie uwarunkowania.

Indywidualne podejście do ucznia ma bezpośrednie przełożenie na organizację nauczania zdalnego w odniesieniu do każdego ucznia. Nauczyciele, działając w oparciu o akty prawne, mają nie tylko prawo, ale i obowiązek samodzielnie decydować o tym w jakiej formie, w jakim zakresie i jak należy dostosować warunki pracy z uczniami i jak realizować podstawę programową. Mając doświadczenie, bazując na sprawdzonych metodach, działaniach, dostępnych materiałach, rozsądku i wypracowanych sposobach pracy można realizować podstawę progra- 
mową. Podstawa programowa dla uczniów niepełnosprawnych intelektualnie w stopniu umiarkowanym i znacznym jest na tyle ogólna, szeroka i spójna z funkcjonowaniem w codziennej rzeczywistości, że właściwie nie ma problemu, by ją swobodnie realizować. Uczniowie z lekką niepełnosprawnością intelektualną realizują te same treści z poszczególnych przedmiotów, co uczniowie ze szkół ogólnodostępnych, jednak forma realizacji tych treści jest dostosowana do możliwości uczniów. Decydują o niej nauczyciele, którzy znają najlepiej swoich uczniów. Bazują na ich mocnych stronach, wykorzystując dostępne w domu przedmioty i sprzęty. Jeśli chodzi o ocenianie uczniów podczas zdalnego nauczania, to każda szkoła ma swoje zasady oceniania, które ustalone zostały na podstawie możliwości uczniów i specyfiki pracy z uczniem niepełnosprawnym.

Uczniowie niepełnosprawni intelektualnie w stopniu umiarkowanym i znacznym oraz uczniowie w edukacji wczesnoszkolnej mają oceny opisowe, a za pomocą cyfry oceniamy uczniów z lekką niepełnosprawnością intelektualną. Ocenić można nie tylko sprawdzian, ale także postawę dziecka, zaangażowanie, wysiłek który wkłada w zdobywanie nowych umiejętności, nawet tych praktycznych, które ułatwiają codzienne ich funkcjonowanie. Jeśli potrzebujemy, to nie bójmy się prosić innych o pomoc, nie wstydźmy się tego, że nie znamy takiej, czy innej aplikacji, że nie mamy pomysłu jak zagospodarować daną przestrzeń. Są obok nas nauczyciele, którzy mają większe doświadczenie w zakresie nowych technologii i mogą okazać się ogromnym wsparciem. Zapewnienie odpowiedniego wsparcia uczniom ze specjalnymi potrzebami wymaga wypracowania specyficznego warsztatu pracy dostosowanego do rodzajów niepełnosprawności i wynikających z nich potrzeb. Metody i formy wsparcia stosowane w toku stacjonarnej pracy nie mają jednak pełnego zastosowania w warunkach pracy zdalnej. Ograniczenie funkcjonowania szkół i przedszkoli w wielu przypadkach doprowadziło do wyhamowania wsparcia dla uczniów z orzeczeniem o potrzebie kształcenia specjalnego. Zapewnienie aktywnego uczestnictwa w procesie dydaktycznym realizowanym na odległość nie jest oczywiście możliwe bez zaangażowania nauczycieli współorganizujących kształcenie. Aktualnie nauczyciele ci pełnią ważną rolę, przekładając podawane treści na język 
zrozumiały dla ucznia i jego rodziców. Ma to ułatwić uczniowi opanowanie treści oraz zapewnić mu uczestniczenie w życiu klasy w takich formach, w jakich jest ono obecnie organizowane. Efektywność działań włączających nadal pozostaje w nierozerwalnym związku z pracą nauczycieli prowadzących poszczególne zajęcia. Każde działanie, a w szczególności działanie wymagające współpracy między uczniami, musi być odpowiednio wcześniej zaplanowane i przedyskutowane przez nauczycieli tak, aby nauczyciel wspomagający miał możliwość uprzedniego ustalenia form i zakresu wsparcia dla ucznia posiadającego orzeczenie. Każdy uczeń ze specjalnymi potrzebami edukacyjnymi musi mieć możliwość uczestniczenia w zajęciach rewalidacyjnych prowadzonych zdalnie. Zajęcia oraz ćwiczenia powinny obecnie koncentrować się na rozwijaniu umiejętności społecznych i komunikacyjnych. Jakkolwiek nie jest błędem przekazywanie rodzicom ćwiczeń, to konieczna jest także praca wymagająca kontaktu z nauczycielem. Wykorzystywane w tym celu narzędzia muszą odpowiadać potrzebom i możliwościom ucznia, jednak warto pamiętać, że zajęcia online prowadzone w czasie rzeczywistym z wykorzysta-niem kamery i mikrofonu są tylko jedną z możliwości. Obecną sytuację warto wykorzystać do rozwijania kompetencji związanych z komunikacją realizowaną w formie pisemnej. Edukacja zdalna nie oznacza, że wykorzystujemy tylko interaktywne zasoby. Poprzez zdalny kontakt możemy uczyć zarówno bazując na tradycyjnych jak i cyfrowych materiałach.

Wybór aktywności zależy od możliwości intelektualnych uczniów. Wiele scenariuszy do pracy zdalnej z uczniami można znaleźć na stronach Epedagogika.pl i Specjalni.pl (bezpośredni link znajduje się w Literaturze na końcu rozdziału). Ponadto na portalach internetowych można znaleźć podpowiedzi, jakie materiały nauczyciel może udostępnić uczniom i jak zaplanować zdalne nauczanie.

Podsumowując, e-learning jest dobrą, chociaż trudną alternatywą w kształceniu osób niepełnosprawnych. Na przeszkodzie staje szereg czynników, które powodują, że wciąż niewiele osób niepełnosprawnych ma szansę uczestniczyć w zajęciach prowadzonych na odległość. Zbyt mała popularność e-kształcenia, zbyt wysokie koszty, brak rozwiniętej infrastruktury i przygotowanej kadry dydaktycznej to najczęstsze przyczy- 
ny niepowodzenia tego typu kształcenia. Zarówno uczniowie, jak i ich bliscy odczuwają brak kontaktu z rówieśnikami, wsparcia i terapii, jednak rosnące zainteresowanie społeczne pozwala mieć nadzieję, że podobnie jak w innych krajach europejskich możliwości zdalnego kształcenia osób niepełnosprawnych w Polsce będą się rozwijać.

\section{Literatura}

https://www.specjalni.pl/2020/03/cwiczenia-i-nauka-online-dlanajmodszych. html\#more [11.03.2020].

Kowalski M. (2020), Nauczanie zdalne uczniów z niepełnosprawnością intelektualną, https://epedagogika.pl/ksztalcenie-i-wychowanie/nauczanie-zdalneuczniow-z-niepelnosprawnoscia-intelektualna-3635.html [01.04.2020].

Kozimior-Cyganik A. (2020), Organizacja zdalnego nauczania dla uczniów ze SPE oraz dla uczniów posiadajqcych orzeczenie o potrzebie kształcenia specjalnego, https://edurada.pl/artykuly/organizacja-zdalnego-nauczania-dlauczniow-ze-spe-oraz-dla-uczniow-posiadaj-cych-orzeczenie-o-potrzebiekszta-cenia-specjalnego/ [04.05.2020].

Rozporządzenie Ministra Edukacji Narodowej z dnia 20 marca 2020 r. w sprawie szczególnych rozwiązań w okresie czasowego ograniczenia funkcjonowania jednostek systemu oświaty w związku z zapobieganiem, przeciwdziałaniem i zwalczaniem COVID-19, Dz.U. 2020 poz. 493

Wapiennik E. (2005), Działania Unii Europejskiej na rzecz osób z niepełnosprawnościq, [w:] D. Gorajewska (red.), Społeczeństwo równych szans tendencje i kierunki zmian, APS, Warszawa. 